\title{
Peningkatan Kapasitas Sumber Daya Manusia PAUD dengan Pelatihan Bahasa Inggris Di Kecamatan Nanggulan Kabupaten Kulon Progo Yogyakarta
}

\author{
Yashinta Farahsani*1, Margaretha Dharmayanti Harmanto² \\ 1Program Studi Teknik Mesin, Fakultas Teknik, Universitas Muhammadiyah Yogyakarta \\ 2Program Studi Akuntansi, Fakultas Ekonomi dan Bisnis, Universitas Muhammadiyah Yogyakarta \\ *e-mail: yashinta_hime@yahoo.com ${ }_{2}^{1}$ retha.dharma@gmail.com²
}

\begin{abstract}
Community service activities, specifically the Community Partnership Program (PKM), aims to improve the ability of Early Childhood Education (PAUD) teachers, both in terms of pronunciation and the methods that support it in Nanggulan sub-district, Kulon Progo district. The target audience for this service program are the PAUD teachers in SPS Tunas Harapan, which amount to 4 (four) people. The programs that have been implemented are training 1) How to pronounce English words, and 2) English methods for PAUD level. The overall process of science and technology transfer is carried out with a pattern of education and training that is equipped with socialization to these teachers to improve the ability and skills to use English developed through English language training (pronunciation on pronunciation or pronunciation) and methods and benefits to improve teacher ability and school quality.
\end{abstract}

Keywords: Capacity building, teachers, PAUD, English training, teaching methods

\section{Abstrak}

Kegiatan pengabdian masyarakat, khususnya program Program Kemitraan Masyarakat (PKM) ini bertujuan untuk meningkatkan kemampuan berbahasa Inggris guru-guru Pendidikan Anak Usia Dini (PAUD), baik dari segi pelafalan maupun metode pengajarannya di kecamatan Nanggulan, kabupaten Kulon Progo. Khalayak sasaran program pengabdian ini adalah guru-guru PAUD di SPS Tunas Harapan yang berjumlah 4 (empat) orang. Adapun ilmu pengetahuan dan teknologi yang ditransfer adalah 1) cara pelafalan kosa kata bahasa Inggris, dan 2) metode pengajaran bahasa Inggris untuk tingkat PAUD. Keseluruhan proses transfer iptek dilaksanakan dengan pola pendidikan dan pelatihan yang meliputi sosialisasi kepada para guru tersebut untuk meningkatkan kemampuan dan ketrampilan berbahasa Inggris yang dikembangkan melalui pelatihan Bahasa Inggris (berfokus pada pelafalan atau pronunciation) dan metode pengajaran Bahasa Inggris untuk anak sehingga diharapkan kegiatan ini dapat digunakan dan bermanfaat untuk peningkatan kapasitas guru dan mutu sekolah.

Kata kunci: Peningkatan kapasitas, guru, PAUD, pelatihan Bahasa Inggris, metode pengajaran

\section{PENDAHULUAN}

Kecamatan Nanggulan berada di ibukota Pemerintah Daerah Tingkat II Kabupaten Kulon Progo Provinsi Yogyakarta. Secara geografis, Kecamatan Nanggulan terletak di sebelah Utara Kulon Progo dengan batas wilayah yaitu Kecamatan Kalibawang di sebelah utara, Kecamatan Sentolo di sebelah selatan, Kecamatan Girimulyo di sebelah barat, dan Kabupaten Sleman di sebelah selatan. Kecamatan Nanggulan secara administratif terbagi 6 (enam) desa (Kembang, Jatisarono, Tanjungharjo, Wijimulyo, Banyuroto, dan Donomulyo) yang meliputi 61 dusun dengan luas total Kecamatan Nanggulan adalah 3.960,67 Ha. Kecamatan Nanggulan merupakan daerah perbukitan dengan ketinggian antara 100-500 meter di atas permukaan air laut, satu daerah dengan Sentolo, Pengasih, dan sebagian Lendah, wilayah dengan lereng antara 2-15\%, tergolong berombak dan bergelombang merupakan peralihan dataran rendah dan perbukitan (https://kulonprogokab.go.id/v3/portal/web/view_detil/6/kondisi-umum).

Iklim di Kecamatan Nanggulan termasuk iklim sub tropis dengan udara yang panas. Dimana, curah hujan di Kecamatan Nanggulan sangat rendah, yaitu rata-rata dalam setahun sebesar $248 \mathrm{~mm} /$ tahun atau $13 \mathrm{~mm} /$ hari. Menurut catatan kantor Badan Pusat Statistik Kulon Progo bahwa Kabupaten Kulon Progo merupakan wilayah yang rawan air akibat curah hujan yang sangat rendah. 
Distribusi penggunaan lahan Kecamatan Nanggulan secara umum dari penggunaan lahan untuk tapak (permukiman, industri, perdagangan, dan fasilitasfasilitas kegiatan lainnya). Dan penggunaan lahan non tapak (perkebunan, sawah, hutan, dan lain-lainnya). Kawasan terbesar kawasan terbangun Kecamatan Nanggulan adalah areal permukiman (perumahan dan berbagai fasilitas sosial -budaya).

Menurut data BPS tahun 2016, kecamatan Nanggulan terdiri dari 7922 kepala keluarga, dengan jumlah penduduk 32.036 jiwa. Di kecamatan Nanggulan terdapat berbagai budaya yang dapat di temukan. Untuk seni tari, terdapat Jathilan yang biasa di pentaskan oleh beberapa dusun di Nanggulan. Selain seni tari, batik pun juga dapat di temukan di kecamatan ini. Dapat juga di temukan salah satu usaha pembuat kain batik tulis maupun cap. Selain itu, makanan khas daerah in adalah geblek. Agama mayoritas di kecamatan ini adalah Islam (91,25\%), sedangkan agama lainnya adalah Katolik (7,92\%) dan Kristen (0,82\%). Tidak ada penduduk yang beragama Hindu atau Buddha.

Dari segi pendidikan, dapat dikatakan bahwa kecamatan ini berada di tingkat menegah ke atas. Hal ini dapat dilihat dari 6 desa yang terdapat di kecamatan ini, berdasarkan data referensi.data.kemdikbud.go.id terdapat 24 SD, baik negeri dan swasta, 1 MI, 5 SMP baik negeri dan swasta, 2 MTs, 1 SMA, 3 SMK, 1 MA. Oleh sebab itu dapat disimpulkan bahwa jumlah SD di kecamatan ini mampu untuk memenuhi kebutuhan warga untuk menempuh pendidikan dasar.

Permasalahan pendidik di sekolah tingkat PAUD di kecamatan Nanggulan ini dapat diidentifikasi sebagai berikut: (a) Tidak ada syarat tingkat pendidikan tertentu untuk menjadi pendidik di PAUD; (b) Kurangnya ketrampilan pendukung dalam melaksanakan kegiatan belajar mengajar di PAUD; (c) Pengenalan Bahasa Inggris pada anak pra sekolah mulai diajarkan di PAUD

Melihat kondisi ini, maka permasalahan yang mendapat prioritas yang harus ditangani adalah: (a) Memberikan pelatihan teaching method untuk anak usia pra sekolah; (b) Memberikan pelatihan Bahasa Inggris untuk pendidik PAUD

\section{METODE}

Kegiatan pengabdian kepada masyarakat dilaksanakn selama 4 (empat) bulan, terhitung sejak Februari - Mei 2019. Inti dari kegiatan dilaksanakan selama 2 (dua) hari, yaitu pada tanggal 10-11 April 2019. Peserta kegiatan pengabdian adalah para pendidik SPS Tunas Harapan, dusun Grubug, desa Jatisarono, kecamatan Nanggulan yang diberikan pelatihan secara bersama-sama di SPS Tunas Harapan. Hal ini dilakukan untuk menambah dan meningkatkan motivasi sesame peserta selama mengikuti kegiatan pengabdian, didukung sarana dan prasarana yang disediakan.

Metode pendekatan yang digunakan dalam pelaksanaan kegiatan pengabdian ini adalah:

a. Sosialisasi program kepada para pendidik PAUD

b. Penyampaian materi tentang metode pengajaran untuk murid PAUD

c. Pelatihan ketrampilan berbahasa Inggris terutama praktek pelafalan kosa kata.

Dalam penelitian ini, peserta latihan mengikuti serangkaian kegiatan untuk mempraktekkan metode pengajaran di hari pertama, dan praktek pelafalan kosa kata di hari kedua. Pada hari pertama, kegiatan ini diawali dengan materi dari pemateri terkait dengan metode pengajaran. Setelah para guru paham dengan materi yang disampaikan, mereka diminta untuk melakukan micro teaching menggunakan metode yang diajarkan. Micro teaching adalah kegiatan mengajar dengan segala aspek pengajarannya diperkecil atau disederhanakan sehingga tidak serumit kegiatan mengajar biasa (Barmawi \& Arifin, 2016: 16). Tujuan dilaksanakan kegiatan ini adalah agar setiap guru memahami metode yang tepat untuk mengajar murid setingkat PAUD sehingga tidak asal dan materi lebih variatif. Pada hari kedua, kegiatan diawali dengan materi dari pemateri terkait dengan cara melafalkan kosa kata dalam Bahasa Inggris. Para guru hanya diminta untuk mempraktekkan pelafalan kosa kata yang biasa dipelajari oleh para peserta didik, misalnya nama-nama binatang, angka, buah, warna, nama hari, nama bulan, dan 
benda-benda di sekitar kita. Pemateri akan mengecek setiap kata yang dilafalkan, apakah sudah benar atau belum.

Model pelaksanaan kegiatan ini dilakukan secara langsung (tatap muka) sebagaimana layaknya temu wicara antara tim pelaksana/tim pengabdi dan peserta kegiatan, yaitu para guru PAUD. Prosedur pelaksanaan kegiatan dimulai dari tahap perencanaan, pelaksanaan, sampai pada proses evaluasi dengan melibatkan semua peserta kegiatan sebanyak 4 (empat) orang. Melalui program ini, diharapkan para pendidik PAUD di kecamatan Nanggulan mendapatkan peningkatan pengetahuan, wawasan, dan kemampuan Bahasa Inggris, serta terampil menerapkan metode pengajaran di kelas. Diharapkan luaran yang diperoleh dari hasil sosialisasi dan pelatihan bagi guru PAUD ini dapat menjadi bekal pengetahuan dan ketrampilan dengan cara berbagi dan menyebarluaskan kepada guru-guru PAUD lainnya, terutama HIMPAUDI agar mereka mampu mengajar anak-anak dengan metode pengajaran yang benar dan mampu memberikan pelajaran Bahasa Inggris dasar dengan pelafalan yang benar pula.

Secara umum prosedur pengabdian ini dibagi menjadi beberapa tahapan, yaitu:

a. Observasi awal (pendahuluan), dimaksudkan untuk mengetahui kondisi sekolah-sekolah PAUD di kecamatan Nanggulan dan potensi guru yang mengajar di sana.

b. Perencanaan, untuk merancang tujuan, materi, strategi, implementor, dan lokasi pengabdian secara terperinci.

c. Implementasi dan pengamatan, untuk mengimplementasikan rancangan yang sudah disusun, serta pencatatan yang dilakukan secara terus-menerus selama proses berlangsung.

d. Evaluasi dan refleksi, untuk mengevaluasi keberhasilan dan hambatan proses pembelajaran yang sudah dilaksanakan.

e. Tindak lanjut, untuk melanjutkan siklus berikutnya dengan mengulang dengan variasi/modifikasi.

Kriteria, indikator pencapaian tujuan dan tolak ukur yang digunakan untuk menjustifikasi tingkat keberhasilan kegiatan pengabdian ini dapat diuraikan sebagai berikut:

Tabel 1. Indikator Keberhasilan program PKM

\begin{tabular}{|c|c|c|c|c|c|}
\hline No & Jenis Pengetahuan & $\begin{array}{c}\text { Sumber } \\
\text { data }\end{array}$ & Indikator & Kriteria Keberhasilan & Instrumen \\
\hline 1 & $\begin{array}{l}\text { Pengetahuan } \\
\text { tentang pentingnya } \\
\text { mengetahui metode } \\
\text { pengajaran yang } \\
\text { tepat untuk anak } \\
\text { PAUD. }\end{array}$ & $\begin{array}{l}\text { Guru } \\
\text { PAUD }\end{array}$ & $\begin{array}{l}\text { Pengetahuan } \\
\text { guru PAUD di } \\
\text { kecamatan } \\
\text { Nanggulan }\end{array}$ & $\begin{array}{l}\text { Terjadi perubahan } \\
\text { yang positif terhadap } \\
\text { pentingnya } \\
\text { menerapkan metode } \\
\text { pengajaran yang tepat } \\
\text { untuk anak PAUD. }\end{array}$ & $\begin{array}{l}\text { Pelatihan dan } \\
\text { micro } \\
\text { teaching }\end{array}$ \\
\hline 2 & $\begin{array}{l}\text { Pengetahuan } \\
\text { tentang pentingnya } \\
\text { ketrampilan Bahasa } \\
\text { Inggris untuk } \\
\text { pengenalan Bahasa } \\
\text { asing kepada murid } \\
\text { PAUD yang meliputi } \\
\text { kosa kata dasar dan } \\
\text { pelafalannya. }\end{array}$ & $\begin{array}{l}\text { Guru } \\
\text { PAUD }\end{array}$ & $\begin{array}{l}\text { Pengetahuan } \\
\text { guru PAUD di } \\
\text { kecamatan } \\
\text { Nanggulan }\end{array}$ & $\begin{array}{l}\text { Terjadi perubahan } \\
\text { yang positif terhadap } \\
\text { pengetahuan guru } \\
\text { PAUD terhadap } \\
\text { pentingnya } \\
\text { ketrampilan Bahasa } \\
\text { Inggris untuk } \\
\text { pengenalan Bahasa } \\
\text { asing kepada murid } \\
\text { PAUD yang meliputi } \\
\text { kosa kata dasar dan } \\
\text { pelafalannya. }\end{array}$ & $\begin{array}{l}\text { Sosialisasi, } \\
\text { ceramah, dan } \\
\text { pelatihan } \\
\text { pronunciation } \\
\text { dengan } \\
\text { melafalkan } \\
\text { beberapa } \\
\text { kosa kata } \\
\text { yang sering } \\
\text { diajarkan ke } \\
\text { murid, } \\
\text { misalnya } \\
\text { angka, buah, } \\
\text { warna, dll. }\end{array}$ \\
\hline
\end{tabular}




\section{HASIL DAN PEMBAHASAN}

Target dalam pengabdian program PKM adalah para pendidik atau guru PAUD di Desa Jatisarono. Desa Jatisarono terletak di Kecamatan Nanggulan, Kabupaten Kulonprogo. Guru PAUD mempunyai peran yang sangat penting, terutama untuk memperkenalkan pendidikan dasar kepada anak usia 3-5 tahun. Menurut Permendiknas Nomor 58 Tahun 2009 Tentang Standar Pendidikan Anak Usia Dini, disebutkan bahwa pendidik anak usia dini adalah professional yang bertugas, melaksanakan proses pembelajaran, dan menilai hasil pembelajaran serta melakukan pembimbingan, pengasuhan, dan perlindungan anak didik (Arifin, 2014). Sebagai fasilitator maka pendidik memiliki peran dalam memberikan kemudahan belajar (facilitate of learning) kepada seluruh peserta didik, agar dapat belajar dalam suasana yang menyenangkan (joyful) gembira (happy/fun), penuh semangat (morale/enthusiast), tidak cemas (in nervous), dan berani mengemukakan pendapat secara terbuka (confident to open opinion) (Mulyasa, 2007 dalam Arifin, 2014). Selain itu, Fitriana (2013: 1) menyebutkan bahwa tenaga pendidik seharusnya sesuai kebutuhan yang berkualifikasi akademik sesuai dengan bidangnya yang tercantum dalam Peraturan Menteri Nomor 16 Tahun 2007 tentang Standar Kualifikasi Akademik dan Kompetensi Guru. Kualifikasi Akademik Guru PAUD/TK/RA harus memiliki kualifikasi akademik pendidikan minimum diploma empat (D-IV) atau sarjana (S1) dalam bidang pendidikan anak usia dini atau psikologi yang diperoleh dari program studi yang terakreditasi.

Berdasarkan permasalahan yang dihadapi mitra, sasaran transfer ipteks adalah 4 (empat) orang guru PAUD yang mengajar di SPS Tunas Harapan, dusun Grubug, desa Jatisarono, kecamatan Nanggulan, untuk diberikan pelatihan dalam hal metode pengajaran dan Bahasa Inggris dasar yang materinya disesuaikan dengan kebutuhan peserta didik dan kurikulum yang berlaku.

Luaran yang dihasilkan dalam program pengabdian masyarakat ini adalah pemberian jasa berupa:

a. Rendahnya kualitas kemampuan tenaga pendidik anak usia dini ini berimplikasi terhadap rendahnya kualitas pendidikan dan pembelajaran yang diselenggarakan di lembaga-lembaga PAUD (Rochayadi, 2014). Adanya peningkatan kemampuan dan ketrampilan berbahasa Inggris para pendidik PAUD menjadi lebih baik, terutama dalam hal kosa kata dan pelafalan (pronunciation) akan menjadi sebuah usaha bagi sekolah tersebut untuk meningkatkan kompetensi guru. Dua hal ini menjadi yang paling penting dalam pengajaran Bahasa Inggris dasar karena peserta didik mulai mengenal Bahasa Inggris melalui gambar dan kosa kata. Selanjutnya, mereka akan belajar untuk mengucapkan kata itu dengan benar. Oleh karena itu, pada pendidik atau guru pun sebaiknya mampu melafalkan setiap kosa kata dengan benar sehingga pelajaran Bahasa Inggris yang didapat di PAUD dapat menjadi dasar yang baik ketika peserta didik melanjutkan sekolah ke jenjang yang lebih tinggi

b. Pendidikan Anak Usia Dini merupakan usaha membina anak yang berumur di bawah 6 tahun dengan metode bermain sambil belajar guna menggali dan mengembangkan bakat, minat dan kreatifitasnya (Sriwahyuni, 2016). Banyak konsep dan fakta yang ditemukan memberikan penjelasan bahwa periode keemasan pada masa usia dini ketika semua potensi anak berkembang paling cepat (Hasan, 2009 dalam Sriwahyuni, 2016). Oleh karenanya, peningkatan kemampuan dalam hal metode pengajaran untuk murid PAUD sangat diperlukan. Transfer ipteks ini diselenggarakan dengan tujuan untuk meningkatkan kemampuan mengajar pendidik agar mereka mempunyai metode yang tepat untuk mengajarkan materi kepada murid-muridnya. Salah satu alasan para pendidik membutuhkan pelatihan ini adalah karena mereka tidak mempunyai dasar sebagai pendidik. Rata-rata pendidik tersebut adalah lulusan SMA yang mengajar PAUD tanpa mempunyai bekal sama sekali. Oleh karenanya, setelah dilaksanakan pelatihan ini, para pendidik dapat mengajar dengan lebih baik.

Selain itu, program pengabdian ini memberikan luaran berupa barang, yaitu perpustakaan mini yang dapat dimanfaatkan para peserta didik sebagai media belajar, terutama 
kosa kata Bahasa Inggris, karena yang disediakan di sana kebanyakan adalah buku-buku cerita berbahasa Inggris dan flash cards. Setiyani (2019: 2) menyebutkan bahwa proses belajar yang efektif antara lain dilakukan melalui membaca. Masyarakat yang gemar membaca memperoleh pengetahuan dan wawasan baru yang akan semakin meningkatkan kecerdasannya sehingga mereka lebih mampu menjawab tentang hidup pada masa-masa mendatang. Selain perpustakaan mini, disediakan juga proyektor mini yang dapat dimanfaatkan untuk menonton film bersama.

Kegiatan pengabdian ini dilaksanakan selama 2 (dua) hari, pada tanggal 10-11 April 2019. Peserta kegiatan pengabdian, guru PAUD di kecamatan Nanggulan diberikan pelatihan secara bersama-sama yang bertempat di SPS Tunas Harapan, dusun Grubug, desa Jatisarono, kecamatan Nanggulan. Program pengabdian masyarakat ini dilakukan dalam bentuk transfer ipteks yang dilakukan dalam bentuk sosialisasi dan pelatihan kepada guru PAUD yang bertujuan untuk meningkatkan kualitas pengajaran dan kemampuan berbahasa Inggris, sehingga diharapkan mereka mampu untuk menggunakan metode pengajaran yang tepat dan mampu untuk melafalkan kosa kata Bahasa Inggris dengan benar. Hal ini akan sangat bermanfaat, bukan hanya untuk pendidik, akan tetapi untuk para murid, karena materi yang disampaikan lebih terserap dan lebih tepat sasaran.

Dipilihnya sasaran guru PAUD, selain mereka yang mempunyai peran penting dalam bidang pengajaran PAUD, mereka juga membutuhkan perluasan wawasan agar mampu memberikan materi yang berguna dan dengan metode yang tepat untuk anak-anak PAUD. Karena mereka tidak mempunyai latar belakang pendidikan PAUD, mereka tidak mempunyai dasar ilmu pedagogik yang kuat. Kebanyakan guru PAUD di daerah sana adalah lulusan SMA yang merupakan kader desa atau kelompok PKK yang menginisasi pengadaan PAUD di desa tempat mereka tinggal. Dengan adanya pelatihan ini, diharapkan akan menambah wawasan mereka terkait metode pengajaran untuk anak usia dini. Selain itu, karena Bahasa Inggris merupakan Bahasa internasional yang mulai dipelajari sejak usia dini, para guru pun harus menyesuaikan kebutuhan siswanya dengan memperkenalkan Bahasa Inggris sejak dini. Pengenalan tersebut dapat berupa pengenalan kosa kata sehari-hari, dengan menunjukkan gambar atau aktivitas lainnya disertai cara pelafalannya.

Adapun langkah-langkah tahapan pelaksanaan program PKM ini adalah:

a. Tahap persiapan dan perancangan yang terdiri dari:

1) Persiapan bahan administrasi sesuai dengan kebutuhan pelaksanaan sosialisasi dan pelatihan,

2) Melakukan koordinasi dengan para guru PAUD di kecamatan Nanggulan sebagai peserta pelatihan,

3) Mempersiapkan materi pelatihan dan narasumber (pemberi materi), disesuaikan dengan target dan tujuan pelatihan,

4) Mempersiapkan jadwal sosialisasi dan pelatihan yang sesuai dengan perencanaan kegiatan yang telah diprogramkan.

b. Tahap implementasi/pelaksanaan dan pengamatan, yang terdiri dari:

1) Sosialisasi dalam bentuk ceramah bervariasi yang terdiri dari:

a) Memberikan pengetahuan dan wawasn tentang ketrampilan berbahasa Inggris dan memberikan contoh-contoh perkembangan bahasa Inggris dalam bidang pengajaran anak.

b) Menjelaskan pentingnya meningkatkan kemampuan dan ketrampilan berbahasa Inggris bagi guru PAUD demi permulaan anak belajar bahasa Inggris, mengingat PAUD adalah sekolah pertama anak, kecuali jika mereka sudah mengenyam pendidikan sejak dititipkan orang tua di penitipan anak (day care).

c) Memberikan pemahaman, peningkatan, serta tips-tips dalam penguasaan ketrampilan bahasa Inggris, terutama penguasaan kosa kata, pelafalan (pronunciation), dan ejaan (spelling). 
d) Diskusi terbatas mengenai pemahaman wawasan yang sudah dikuasai oleh para pendidik PAUD.

2) Pelatihan terdiri dari:

a) Pelatihan metode pengajaran bahasa Inggris untuk anak usia dini.

b) Pelatihan pelafalan bahasa Inggris.

c. Tahap evaluasi dan refleksi, untuk mengevaluasi keberhasilan dan hambatan proses pembelajaran yang sudah dilaksanakan yang terdiri dari:

1) Presentasi kesimpulan sosialisasi oleh tim pelaksana dan praktek pelatihan langsung oleh peserta,

2) Refleksi berupa praktek dari hasil pelatihan,

3) Pemberian penilaian terhadap hasil pembelajaran selama pelatihan kepada para peserta,

4) Tindak lanjut, untuk melanjutkan siklus berikutnya dengan mengulang dengan variasi/modifikasi.

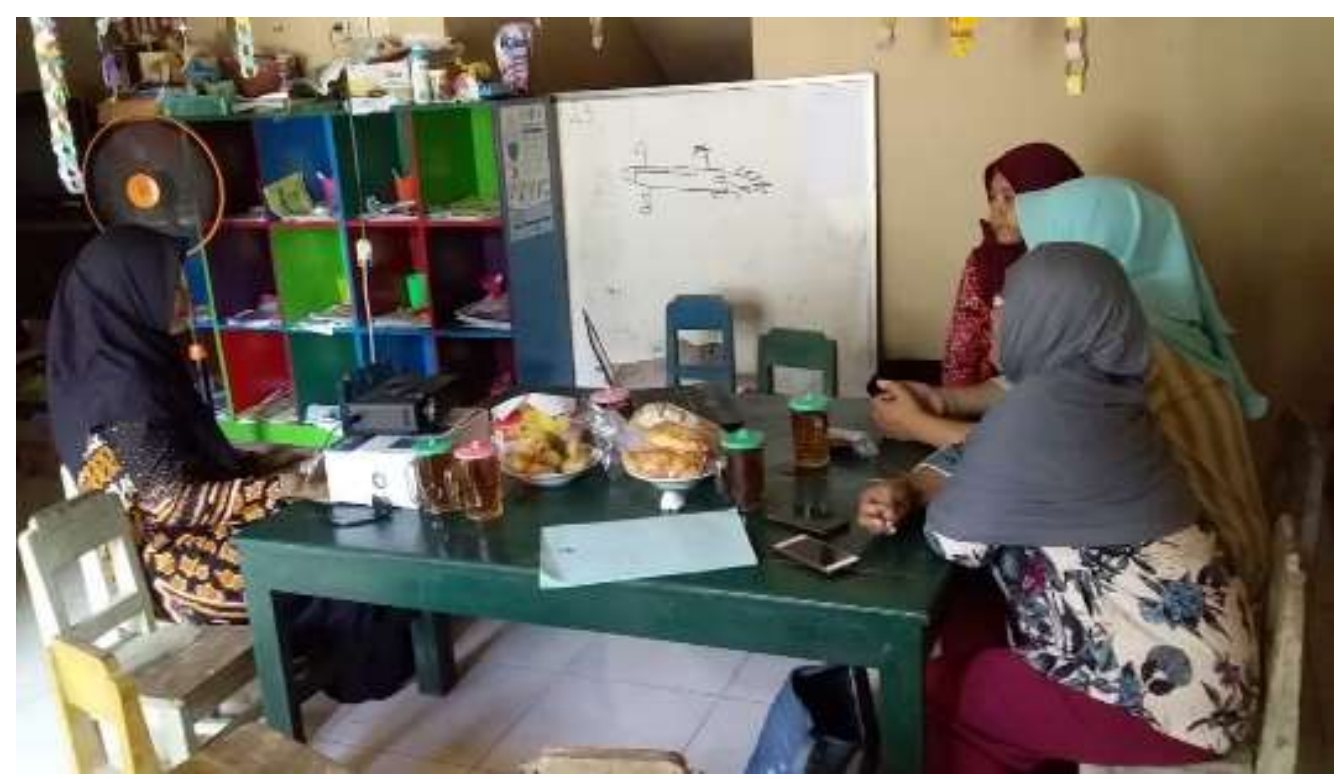

Gambar 1. Dokumentasi pelatihan guru PAUD

\section{KESIMPULAN}

a. Partisipasi mitra program pengabdian masyarakat sangat tinggi. Hal ini memberikan dampak positif bagi pelaksanaan program, terlihat dari keikutsertaan mereka dalam sosialisasi dan pelatihan metode pengajaran bahasa Inggris untuk anak usia dini dan pelafalan kosa kata bahasa Inggris.

b. Dihasilkannya luaran-luaran program seperti yang diharapkan oleh program pengabdian masyarakat ini. Selain adanya pelatihan, tim juga berhasil membuat perpustakaan kecil untuk media belajar para murid PAUD di salah satu PAUD di kecamatan Nanggulan.

\section{UCAPAN TERIMA KASIH}

Penulis mengucapkan terima kasih kepada LP3M Universitas Muhammadiyah Yogyakarta atas dukungan finansial sehingga penulis dapat melaksanakan program pengabdian ini dengan baik. Selain itu, penulis juga mengucapkan terima kasih kepada sekolah-sekolah PAUD di dusun Grubug, Jatisarono, Nanggulan, Kulon Progo, Yogyakarta atas partisipasinya dalam program pengabdian ini. 


\section{DAFTAR PUSTAKA}

Arifin, Ar-Raisul Karama dan Nur Ainy Fardana. 2014. Peran Pendidik PAUD dalaam Mengimplementasikan Pendidikan Karakter Melalui Metode Pembelajaran Sentra dan Lingkaran. JURNAL Psikologi Pendidikan dan Perkembangan. 3(3): 199-198

Barmawi \& M. Arifin. (2016). Micro Teaching (Praktik Pengajaran yang Efektif \& Kreatif). Yogyakarta: Ar-Ruzz Media.

Fitriana, Andita. 2013. Upaya Pengembangan Kompetensi Profesional Guru Taman Kanak-Kanak di Kecamatan Bantul, Kabupaten Bantul [Skripsi]. Yogyakarta (ID): Universitas Negeri Yogyakarta

Hasan Maimunah. 2009. Pendidikan Anak Usia Dini. Jogjakarta: DIVA Press.

https://kulonprogokab.bps.go.id/

https://kulonprogokab.go.id/v3/portal/web/view_detil/6/kondisi-umum

Mulyasa, E. (2007). Standar Kompetensi dan Sertifikasi Guru. Bandung: PT Remaja Rosdakarya Offset

Rochayadi, Iman. 2014. Upaya Meningkatkan Kompetensi Guru PAUD Melalui Pendidikan dan Pelatihan Guru di PAUD Bougenville Kecamatan Sukajadi Kota Bandung. Jurnal Empowerment. 4(1): $1-10$

Setiyani, Ikom. 2019. Mengembangkan Minat Baca Anak Usia Dini Melalui Kegiatan Literasi Perpustakaan di TK Masyithoh 25 Sokaraja [Skripsi]. Purwokerto (ID): IAIN Purwokerto

Sriwahyuni, Eci dan Nofialdi. 2016. Metode Pembelajaran yang Digunakan PAUD (Pendidikan Anak Usia Dini) Permata Bunda. Jurnal Thufula. 4(1): 44-62 